\title{
Evaluating the Trend of Changes in Bed Sediments Gradation over the Sistan River
}

\author{
Mahdi Motallebian ${ }^{1}$, Farzad Hassanpour ${ }^{2}$, and Hadi Kamell ${ }^{3 \times 凶}$ \\ ${ }^{1}$ Ph.D. Student of Hydraulic Structures, Dept. of Water Engineering, Urmia University, Iran \\ ${ }^{2}$ Associate Professor, Dept. of Water Engineering, University of Zabol, Iran \\ ${ }^{3}$ Graduted in Water Engineering, University of Zabol, Iran \\ ${ }^{\star}$ Corresponding author’s Email: hadi.kamel@gmail.com
}

\begin{abstract}
Sediment movement in rivers is one of the most important indicators to evaluate the health of an ecosystem. Bed load different specification such as shape, dimensions and other statistical parameters of this sediment reflect the hydraulic and hydrological conditions governing them, directly. To investigate the changes of particle aggregation of Sistan river bed, four sediment samples were collected from the Sistan river. After aggregation of sediments in the laboratory, sediment diameter (D50) and uniformity coefficient $(\mathrm{Cu})$ was calculated, and using inverse distance weighting (IDW) method, the mentioned parameters for the Sistan river from Jarikeh up to the AfzalAbad plugs place were interpolated and parameters using ARC-GIS software was zoning along the river. Results showed that Sistan river bed material is sand and silt, $3 \mathrm{~km}$ to the beginning and at end of the study interval based on the English standard classification it is silty texture and the rest of bed is sandy texture. 11 kilometers beginning and the end of the river also from $20+721$ kilometer up to about 12 kilometers has also a good aggregation. The entire river except for the middle section of river from the $13+244 \mathrm{~km}$ to extent of $4 \mathrm{~km}$ river bed has non-uniform soil.
\end{abstract}

Keywords: Sistan River, bed Gradation, ARC-GIS, IDW method.

\section{INTRODUCTION}

Sediment production is one of the important consequences of soil erosion that variety of forms will causing specific effects of intra-regional and regional output (Williams, 1983). Soil erosion and sediment production of major constraints on sustainable use of soil and water resources is known, hence the evaluation of the processes governing the their behavior, in order to better understand and describe appropriate management practices are essential (Sadeghi et al., 2011). Investigation of sediment movement in rivers for correct understanding morphology and hydraulically behavior of the river is a very important issue (Rahattalab nakhiri et al., 2000). One of the most important principles of sedimentary basins is Particles size reduction toward river downstream (Heitmuller and Hudson, 2009). Particle size in the rivers with gravelly bed load toward downstream is reduced exponentially that it is one of the main features of rivers and one of the factors controller of morphology and hydraulics of canal. Two abrasion and hydraulic sorting processes has role in trend of particle size changes the downstream in such rivers (Rice, 1999; Church, 1999; Surian, 1999). Bed sediments during motion are mainly in contact with the cannel bed and Remain behind. On the other hand bed load different specification such as shape, dimensions and other statistical parameters of this sediment reflect the hydraulic and hydrological conditions governing them, directly (Williams, 1983). Research on trend and how to change various properties of bed sediments along the river has a relatively long history (as example: Williams, 1983; Koche and Baker, 1988; Davide et al., 2003; Heitmuller and Hudson, 2009; Snelder et al, 2011). After the formation of the Sistan Great Lake which its precipitates exist in both Afghanistan and Iran countries that slow sedimentation as a mixture of silt, very fine sand and clay, it has started (Absaran Consulting Engineers, 2008). Located on the tailwater of Helmand River basin, Sistan River receives huge amounts of sediments every year. The results of the frequency analysis of the data related to sedimentation measurement shows that the amount of sediments entering Sistan River is about 7 million tons per year. In flood with return cycles of 5, 10, 100 and 200 years, this figure is respectively 11.5, 14.5, 24 and 36 million tons. A large portion of these sediments are 
deposited across Sistan River, which results in the enlargement of bed level (Consulting Engineers of Tehran Sahab, 1992). Sistan river's low slope of the bed makes it prone to sedimentation and the negative effects of improper utilization of the Zahak dam has intensified the sedimentation of the upper river and the uniform changes in substrate profiles in bed from Zahak dam to the two branches of the upstream end of the flow reveals that the increase in the bed of the kohak dam is influenced by the utilization of Zahak dam (Hssanpour, 2008). Studies done show that hand bed load different specification such as shape, dimensions and other statistical parameters of this sediment reflect the hydraulic and hydrological conditions governing them, directly. Therefore, this study was conducted to evaluate the changes in bed particle size in Sistan River.

\section{MATERIALS AND METHODS}

\section{Location of the study area}

Helmand River in Afghanistan travels about 1,100 kilometers in Afghan land and in the border of Iran and Afghanistan it branches into Priyan and Sistan. Sistan River is the main source of water in the plain and after traveling about $70 \mathrm{~km}$ from the Sistan plain it flows into the Helmand River. This river with the general slope of 0.00002 to 0.00006 from the level of $489 \mathrm{~m}$ gets to the 474.75m level in Hamun of Helmand (Hssanpour, 2008). (Figure 1). Shows an overview of the position of Sistan and Sistan River.

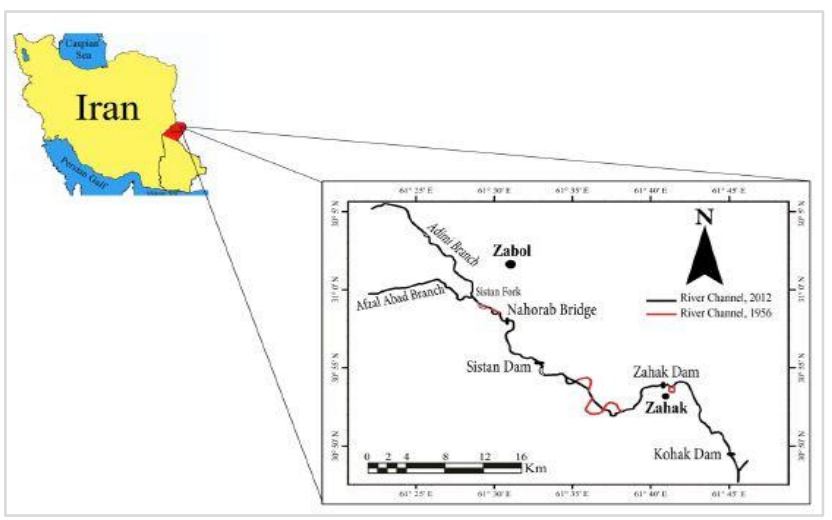

Figure 1. Position of Sistan region and plan of Sistan River

\section{Sampling of bed sediments}

To investigate the changes of particle aggregation of Sistan river bed, four sediment samples were collected from the river bed. Figure 2, shows the sampling location on the river.

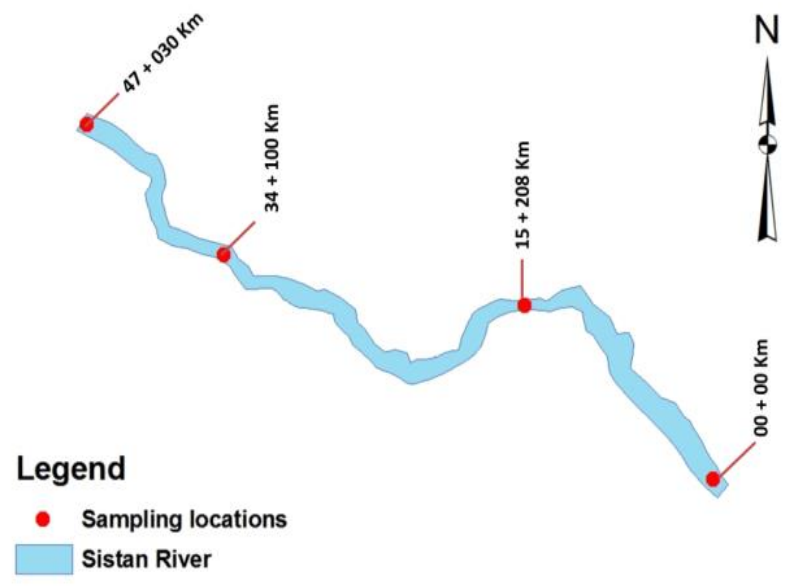

Figure 2. Sampling location on the river

\section{Classification of soils according to their size}

Soils according to the size to gravel, sand, silt and clay are classified.

Table 1. Classification of soils

\begin{tabular}{lcccc}
\hline $\begin{array}{l}\text { Soil } \\
\text { texture }\end{array}$ & $\begin{array}{c}\text { English } \\
\text { Standard }\end{array}$ & AASHTO & ASTM & Unified \\
\hline Gravel & $2-60$ & $2-75$ & $>2$ & $4.75-75$ \\
\hline Sand & $0.06-2$ & $0.05-2$ & $0.075-2$ & $0.075-4.75$ \\
\hline Silt & $0.002-0.06$ & $0.002-0.05$ & $0.005-0.075$ & $\begin{array}{c}<0.075 \\
\text { Fine } \\
\text { aggregate }\end{array}$ \\
\hline Clay & $<0.002$ & $<0 / 002$ & $<0.005$ & \\
\hline
\end{tabular}

\section{Soil gradation concepts}

Soil gradation is a classification of a coarsegrained soil that ranks the soil based on the different particle sizes contained in the soil. Soil gradation is an important aspect of soil mechanics and geotechnical engineering because it is an indicator of other engineering properties such as compressibility, shear strength, and hydraulic conductivity. In a design, the gradation of the in situ or on site soil often controls the design and ground water drainage of the site. A poorly graded soil will have better drainage than a well graded soil.

Uniform soil: If a significant percentage of soil particle size is being in a certain range to be called a uniform soil.

Non-uniform soil: If particle size be in the wide range called a non- uniform soil.

Well graded soil: A well graded soil is a soil that contains particles of a wide range of sizes and has a good representation of all sizes from the No.4 to No.200 sieves.

Poorly graded soil: A poorly graded soil is a soil that does not have a good representation of all sizes of particles from the No.4 to No.200 sieve. Poorly graded soils are either uniformly graded or gap-graded. 
The coefficient of uniformity: $\mathrm{Cu}$ is a crude shape parameter and is calculated using the following equation:

$$
C_{u}=\frac{D_{60}}{D_{10}}
$$

Where D60 is the grain diameter at $60 \%$ passing, and D10 is the grain diameter at $10 \%$ passing.

The coefficient of curvature: $\mathrm{Cc}$ is a shape parameter and is calculated using the following equation:

$$
C_{c}=\frac{\left(D_{30}\right)^{2}}{D_{10} \times D_{60}}
$$

Where D60 is the grain diameter at $60 \%$ passing, $\mathrm{D} 30$ is the grain diameter at $30 \%$ passing, and D10 is the grain diameter at $10 \%$ passing.

Once the coefficient of uniformity and the coefficient of curvature have been calculated, they must be compared to published gradation criteria

\section{Criteria for grading soils}

The following criteria are in accordance with the Unified Soil Classification System:

For a gravel to be classified as well graded, the following criteria must be met: $\mathrm{Cu}>4 \& 1<\mathrm{Cc}<3$

If both of these criteria are not met, the gravel is classified as poorly graded or GP. If both of these criteria are met, the gravel is classified as well graded or GW.

For a sand to be classified as well graded, the following criteria must be met: $\mathrm{Cu} \geq 6 \& 1<\mathrm{Cc}<3$

If both of these criteria are not met, the sand is classified as poorly graded or SP. If both of these criteria are met, the sand is classified as well graded or SW.

\section{ARC-GIS software}

Arc-GIS software is very easy software to GIS Applications that allows users to use spatial data and descriptive data to make maps, tables and charts, easily. In other words, Arc-GIS is a software tools required for data analysis, data search and display results with suitable quality and acceptable puts the user (Tate, 1998).

ArcGIS applications in the general case in the twolevel of design and database management and map production and editing, with data spatial analysis are divided. This Division is reflected in the form Arc MAP and Arc Catalog. So Arc Catalog and Arc MAP play a role respectively in the data management and the data generation and analysis. One advantage of ArcGIS having programs that is no need to install. These programs having various applications are in the spatial data analysis, etc. In general can say that the very high power of ArcGIS software in the spatial analysis and management of databases is which has distinguished it from other similar software (Chae Kwan, 2003). This software were used in this research for zoning bed sediment parameters along the river.

\section{Inverse distance weighting (IDW)}

All interpolation methods have been developed based on the theory that points closer to each other have more correlations and similarities than those farther. In IDW method, it is assumed substantially that the rate of correlations and similarities between neighbors is proportional to the distance between them that can be defined as a distance reverse function of every point from neighboring points. It is necessary to remember that the definition of neighboring radius and the related power to the distance reverse function are considered as important problems in this method. This method will be used by a state in which there are enough sample points with a suitable dispersion in local scale levels. The main factor affecting the accuracy of inverse distance interpolator is the value of the power parameter. In this study, we compared estimates of inverse distance interpolator using different integer powers parameters 1, 2, 3, 4 and 5, which are the most commonly used in literature. Since, the goal of using inverse distance functions as estimators is giving more weight (importance) to the closest sampled points, in this study we just considered integer values of $p$ parameter, because the values lower than one are closest to a simple average estimation. In addition, the size of the neighborhood and the number of neighbors are also relevant to the accuracy of the results.

$$
z_{0}=\frac{\sum_{i=1}^{N} z_{i} \cdot d_{i}^{-n}}{\sum_{i=1}^{N} d_{i}^{-n}}
$$

Where:

$\mathrm{ZO}=$ The estimation value of variable $\mathrm{z}$ in point $\mathrm{I}$.

$\mathrm{Zi}=$ The sample value in point $\mathrm{I}$.

$\mathrm{di}=$ The distance of sample point to estimated point.

$\mathrm{N}=$ The coefficient that determines weigh based on a distance.

$\mathrm{n}=$ The total number of predictions for each validation case.

\section{RESULTS AND DISCUSSION}

To investigate the changes of particle aggregation of Sistan river bed, four sediment samples were collected from kohak Hydrometric station, Downstream of the Zahak dam, Downstream of the Sistan dam, Downstream of the Nohurab Bridge and Samples were transported to the Laboratory of Soil Mechanics and were granulated Hydrometry and sieve analysis. Gradation curves are shown in Figures 3 to 6. After aggregation of sediments, sediment diameter (D50) and uniformity coefficient $(\mathrm{Cu})$ 
was calculated, and Using IDW method, the mentioned parameters for the Sistan River from Jarikeh plugs up to the Afzal Abad plugs place were interpolated and Parameters using ARC-GIS software was zoning along the river. The results are presented in Figures 3-6.

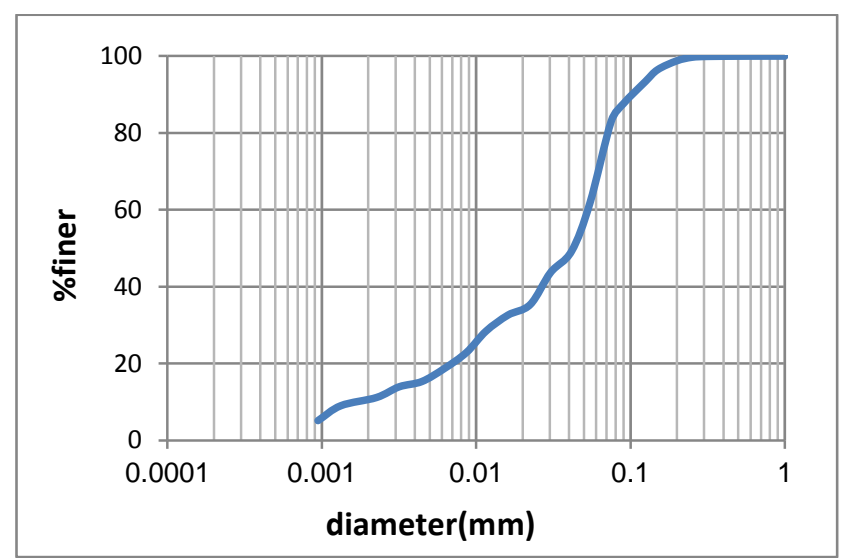

Figure 3. Grading Curve of kohak Hydrometric station

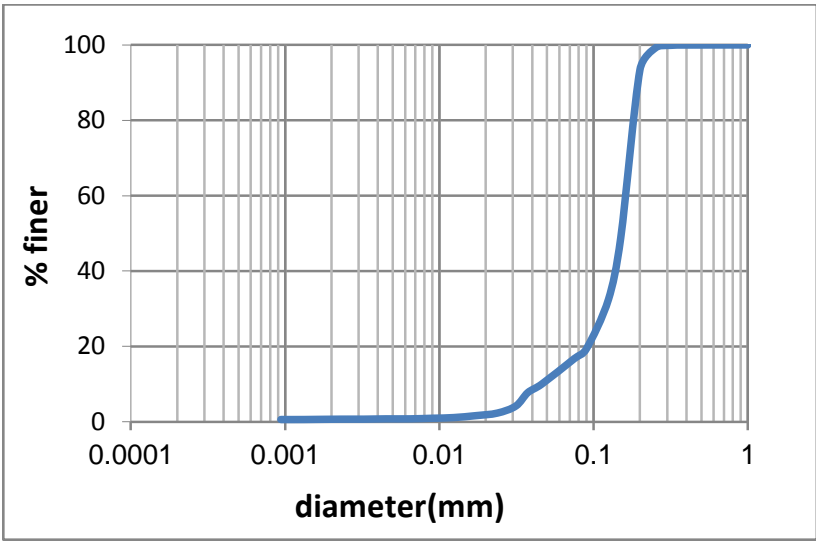

Figure 4. Grading Curve of Downstream of the Zahak dam

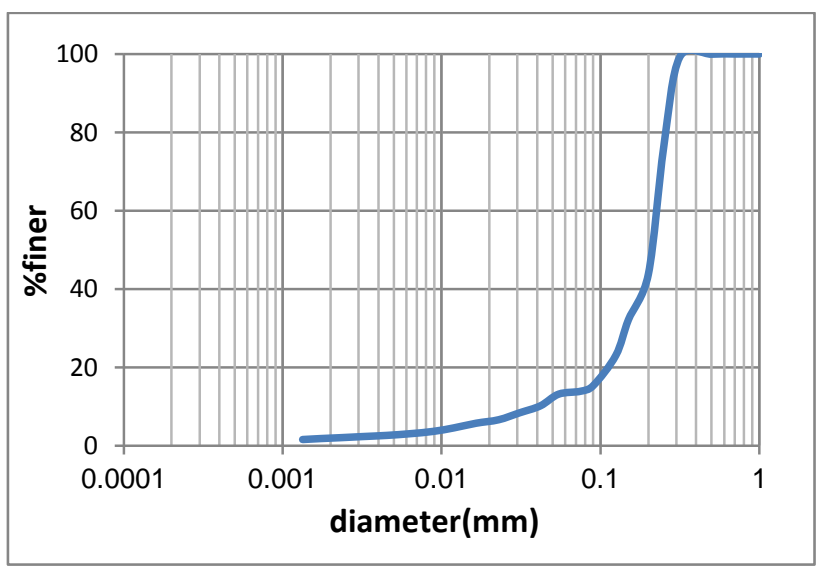

Figure 5. Grading Curve of Downstream of the Sistan dam

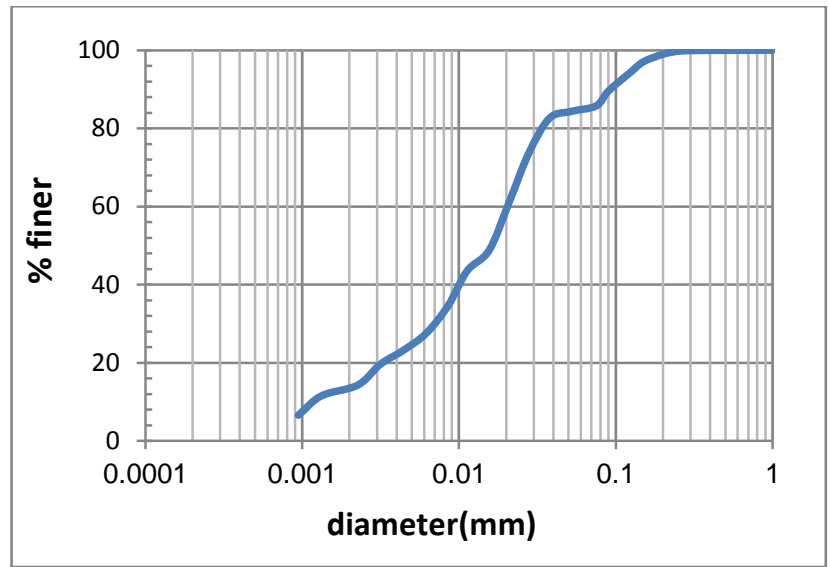

Figure 6. Grading Curve of Downstream of the Nohurab Bridge

Mode of $\mathrm{Cu}$ changes along the river in Figure 7. are presented that show the range of $11 \mathrm{~km}$ of the beginning and end of the river, as well as the interval [32185-20721], which is approximately 12 kilometers have Well Graded and the river except for the interval [17590-13244] (about $4 \mathrm{~km}$ ) has a bed with non-uniform soil.
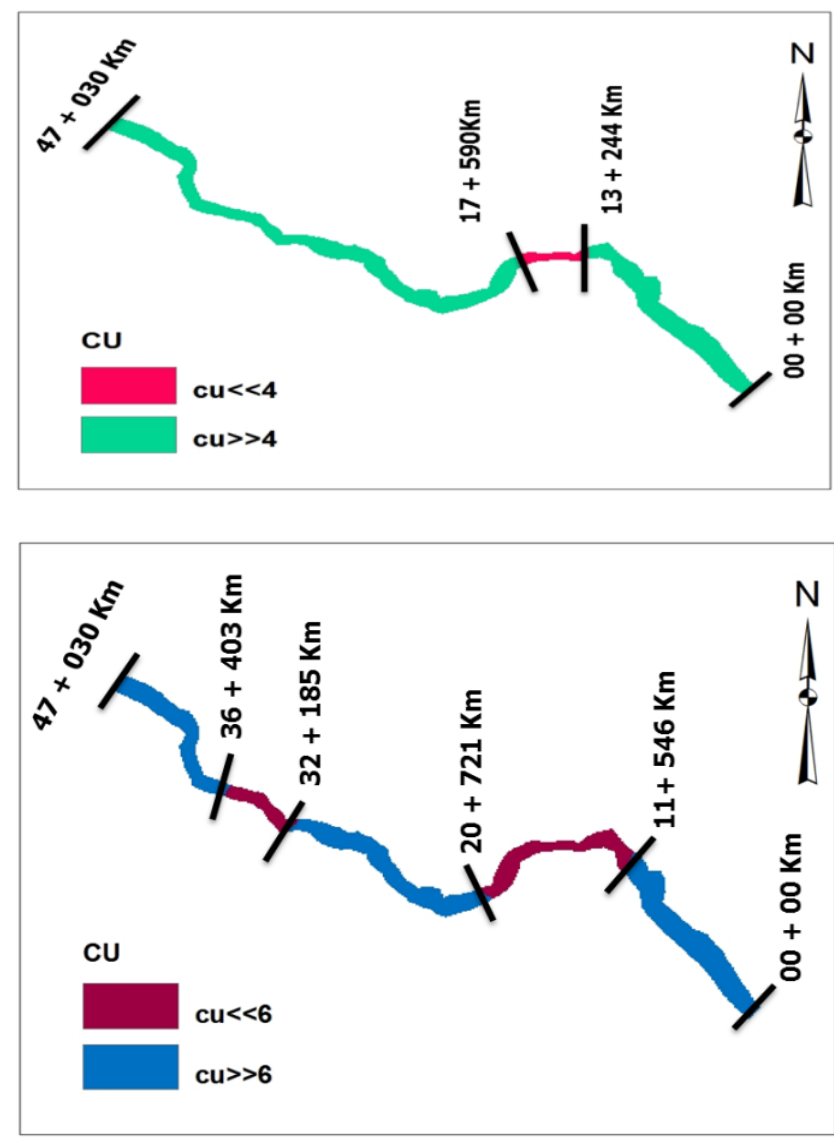

Figure 7. Zoning map of $\mathrm{Cu}$ changes along the river 
Mode of D50 changes based on various classifications 10 are presented in Figures 7-9. Figure 8. Shows that $3 \mathrm{~km}$ to the beginning and end of the river based on the English standard classification is silty texture and the rest of bed is sandy texture.

Figure 9 shows that $1.671 \mathrm{~km}$ to the beginning of the river and $3.311 \mathrm{~km}$ end of the river based on the AASHTO classification is silty texture and the rest of bed is sandy texture. Figure10 shows that $4 \mathrm{~km}$ to the beginning of the river and $4.421 \mathrm{~km}$ end of the river based on the ASTM classification is silty texture and the rest of bed is sandy texture. Figure 11 shows that $4 \mathrm{~km}$ the beginning of the river and $4.421 \mathrm{~km}$ end of the river based on the Unified classification is Fine aggregate texture and the rest of bed is sandy texture.

According to various classifications intervals beginning and end of the river bed is silty and the rest of bed is sandy texture.
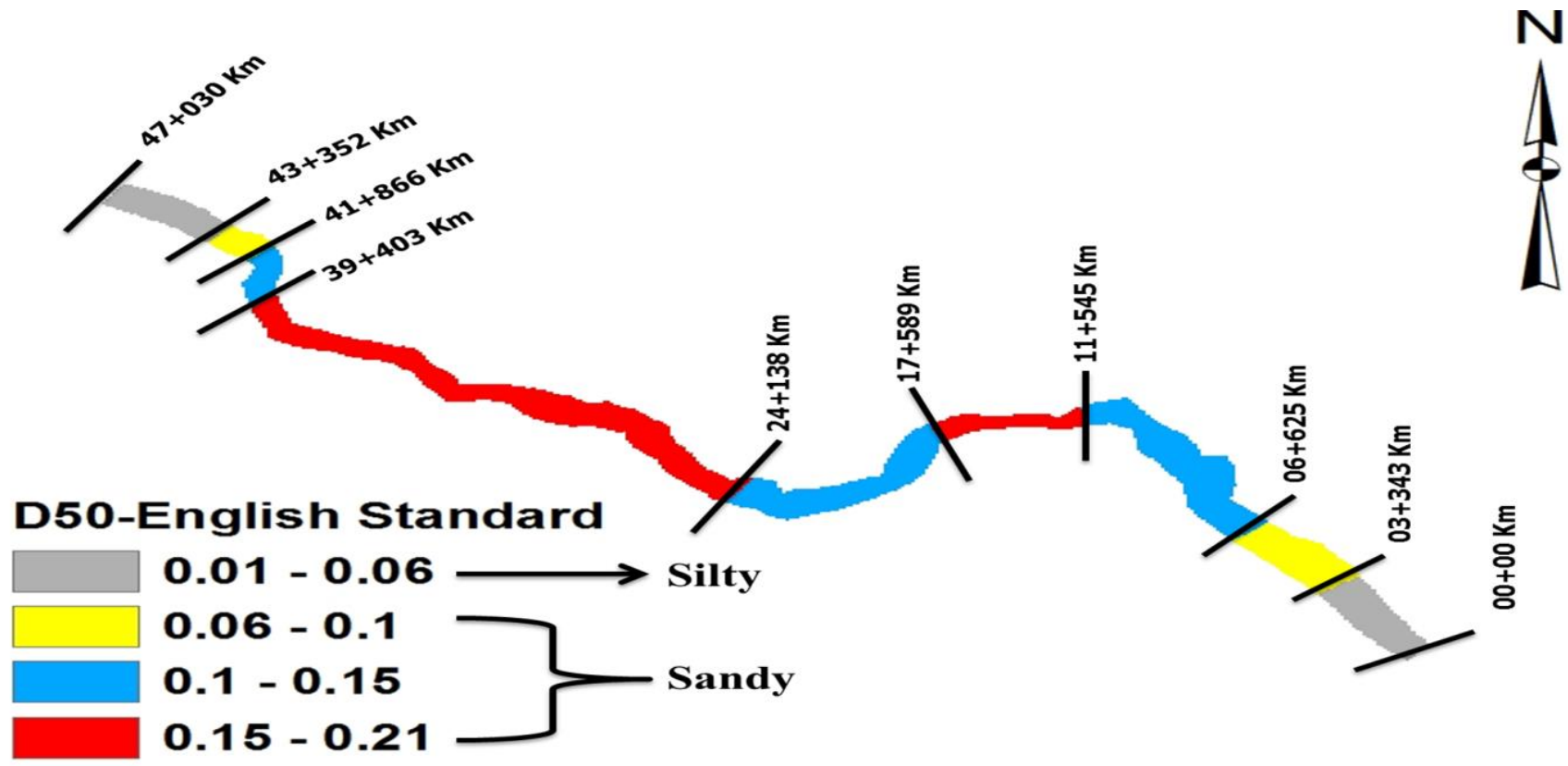

Figure 8. Zoning map of D50 changes along the river based on the English standard classification

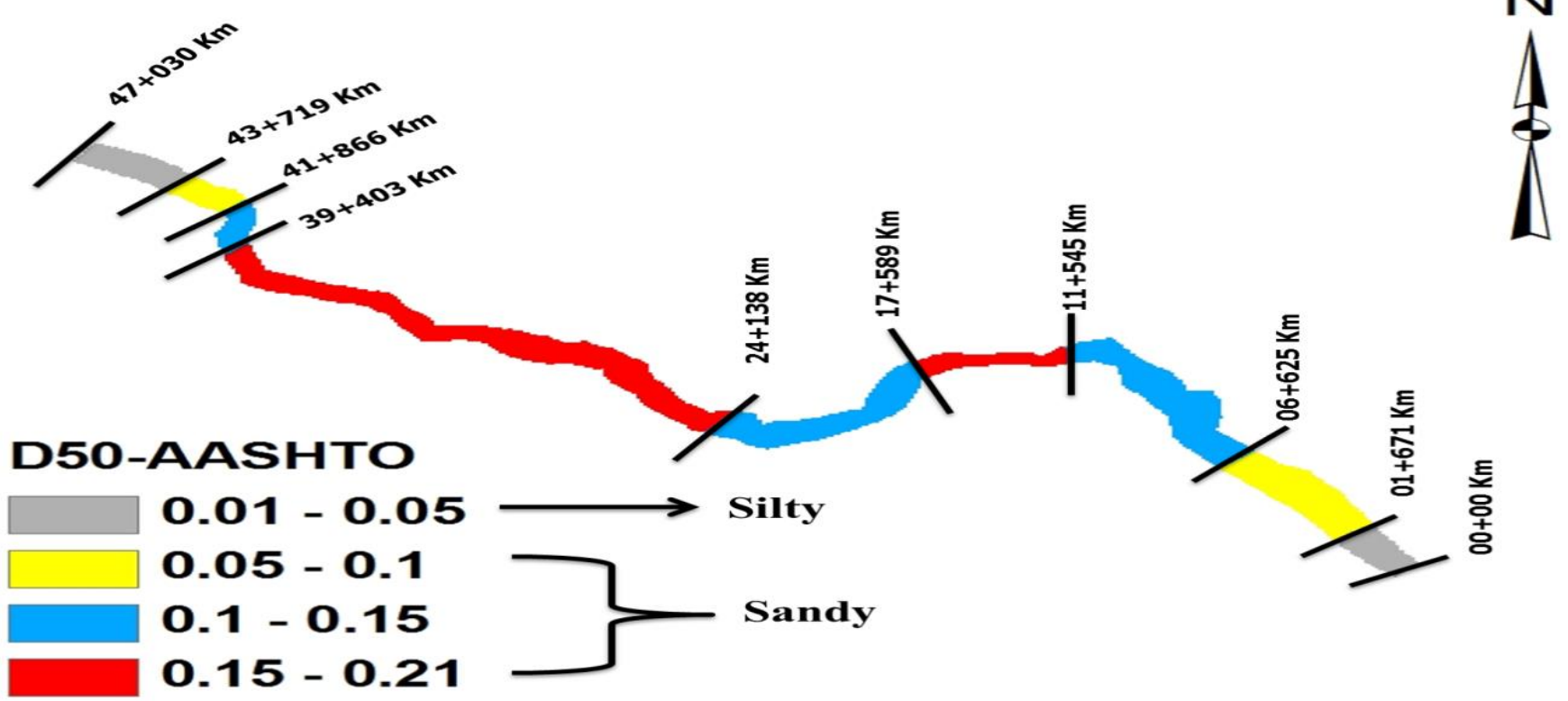

Figure 9. Zoning map of D50 changes along the river based on the AASHTO classification 

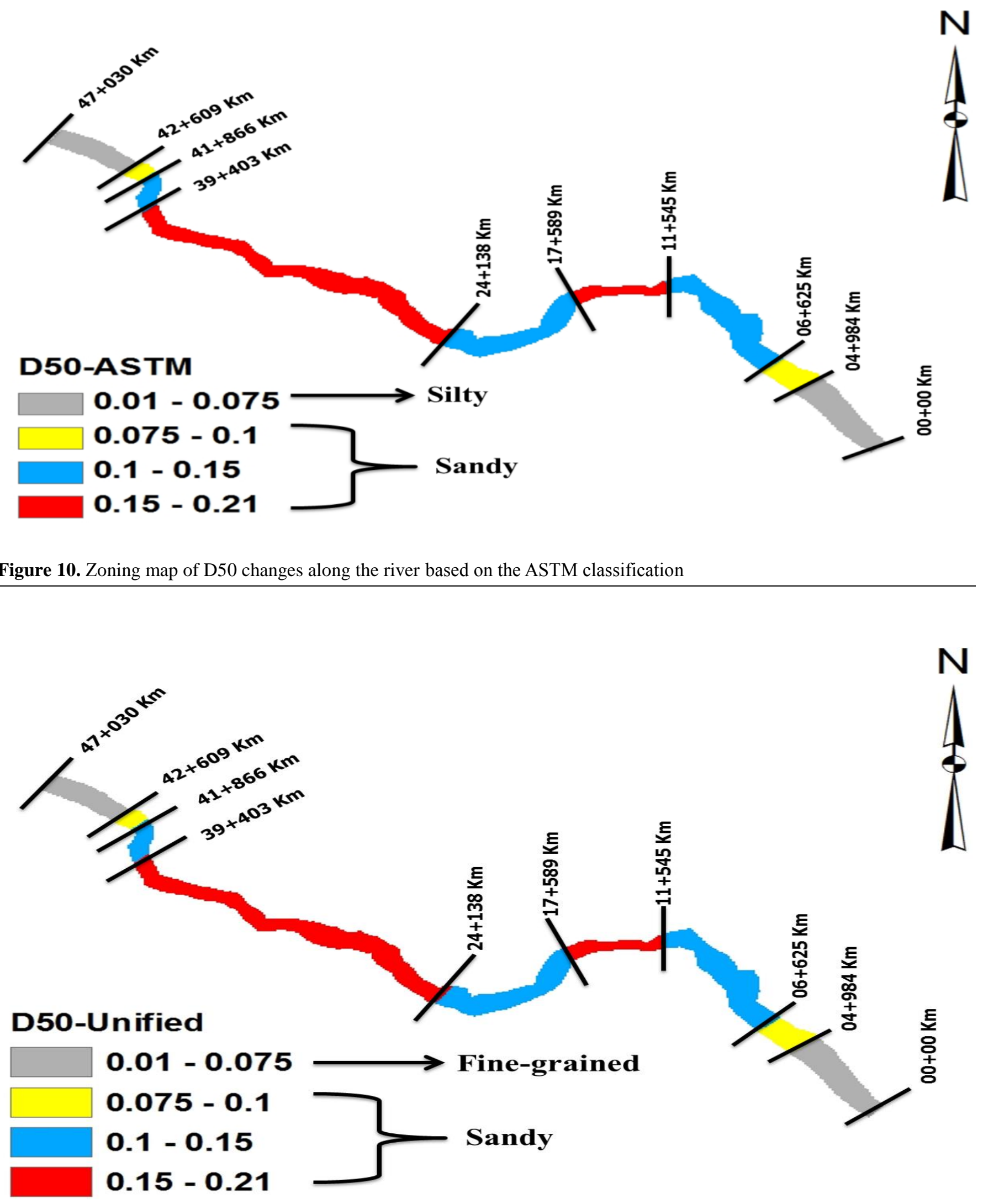

Figure 11. Zoning map of D50 changes along the river based on the Unified classification 


\section{CONCLUSION}

In this study how changes of two important parameters of sediments studied along the Sistan River. Results showed that Sistan river bed material is sand and silt that $3 \mathrm{~km}$ to the beginning and end of the study interval based on the English standard classification is silty texture and the rest of bed is sandy texture. 11 kilometers beginning and the end of the river also from $20+721$ kilometer up to about 12 kilometers so it has a good aggregation. The entire river except for river middle section from the $13+244 \mathrm{~km}$ to extent of $4 \mathrm{~km}$ so it river bed has non-uniform soil. The results also showed that whole Sistan river bed materials is sand and silt that Conformity with the reports of Absaran Consulting Engineers in 2008.

\section{DECLARATIONS}

\section{Acknowledgement}

From respected authority of Regional Water Corporation of the Zabol to share data is gratitude.

\section{Conflict of interest statement}

I hereby states that, there is no conflict of interest whatsoever with any third party.

\section{REFERENCES}

Absaran Consulting Engineers (2008). River Sistan Flood Control studies, Soil and Water Development Corporation of Sistan. Ministry of Energy.

Chae Kwan L (2003). Applying GIS to Hydraulic Analysis. Journal of Environmental Hydrology, 129: 97-107. Google $\underline{\text { Scholar }}$

Church WC (1999) Sediment sorting in gravel-bed rivers. J. Sediment. Res. 69A. 20. Link

Davide V, Pardos M, Diserens J, Ugazio G, Thomas R, Dominik J. (2003). Characterisation of bed sediments and suspension of the river Po (Italy) during normal and high flow conditions. Water research. 37(12): 2847-64. https://doi.org/10.1016/S0043-1354(03)00133-7

Heitmuller F and Hudson PF (2009). Downstream trends in sediment size and composition of channel-bed, bar, and bank deposits related to hydrologic and lithologic controls in the Liano river watershed, central Texas, USA. Geomorphology 112: 246-260.

Hssanpour F (2000). Detecting the critical points of sedimentation and defining the optimal interval dredging using mathematical models (The analysis of Sistan River). Completed a master Thesis, Faculty of Agriculture, TarbiatModarres University, Tehran

Kochel RC, Baker VR. (1988). Paleoflood analysis using slackwater deposits. Flood Geomorphology. John Wiley and Sons Publications. 1: 357-76. https://arizona.pure.elsevier.com/en/publications/paleoflood -analysis-using-slackwater-deposits

Rahattalab nakhjiri H, Golmayee H, Yusefi H, Ektayee R. (2004). Evaluation and selection of the most appropriate ways to estimate the rivers load bed (Case study: zarrin river of golestan province), Journal of Agriculture and Natural Resources, p. 133-140.

Rice S (1999). The nature and controls on downstream fining within sedimentary links. Journal of Sedimentary Research. 69(1): 32-9. https://doi.org/10.2110/jsr.69.32

Sadeghi SHR, Kheyrfam H (2011). Effect harvesting gravel and sand transport rate of suspended load and bed load in Kojour River. Fifth national conference on watershed management and soil and water resources management.

Snelder TH, Lamouroux N, Pella H. (2011). Empirical modelling of large scale patterns in river bed surface grain size. Geomorphology. 127(3-4): 189-97. https://doi.org/10.1016/j.geomorph.2010.12.015

Surian N (2002) Downstream variation in grain size along an Alpine River, analysis of controls and processes. Geomorphology 43(1-2):137-149. https://doi.org/10.1016/S0169-555X(01)00127-1

Tate EC (1998). Floodplain mapping using HEC-RAS and ArcView GIS. Master Thesis. Department of Civil Engineering. University of Texas at Austin. 137p.

Tehran Sahab Consulting Engineers (1990). Scheme of optimal utilization of the Helmand River. Consulting Engineers Tehran Sahab. The Hydrology report, Ministry of Energy Regional Water Company of Sistan and Baluchistan, 10 pages.

Williams GP (1983). Paleohydrological methods and some examples from Swedish fluvial environments: I cobble and boulder deposits. Geografiska Annaler: Series A, Physical Geography. 65(3-4): 227-43. https://doi.org/10.1080/04353676.1983.11880088 